\title{
Sedm Husových pravidel o pravdě
}

\section{Vážení čtenáři,}

není snad letošního roku významnějšího výročí než 600 let, které uplynulo od mučednické smrti Mistra Jana Husa, především reformátora katolické církve, ale rovněž i akademického pracovníka, učitele a vědce, který v letech 1409 až 1411 vykonával funkci rektora Univerzity Karlovy v Praze. Jeho vědecké dílo obsahuje přibližně šedesát česky i latinsky psaných učených pojednání, tzv. traktátů, přičemž k nejcitovanějším publikacím patří český Výklad viery (1412) či latinský De Ecclesia (1413). Ve svých dílech se často zabýval problematikou pravdy a jejího správného pochopení, svým žákům a dalším čtenářům vzkázal: ${ }^{1}$ „... hledaj pravdy, slyš pravdu, uč sě pravdě, prav pravdu, miluj pravdu, drž pravdu, bran̆ pravdu až do smrti; ..."“

Domnívám se, že ačkoliv autor tento vzkaz uvedl v díle teologickém, nebude $\mathrm{v}$ rozporu s jeho učením, když uvedené příkazy označím za pravidla o pravdě a aplikuji je obecně na práci vědeckou. ${ }^{2}$

\section{Pravidlo první: Hledaj pravdy!}

Bez tohoto prvního pravidla by vlastně ani žádná věda neexistovala. Hledání pravdy by mělo spočívat v používání odpovídajících vědeckých metod, od studia dosavadního poznání (viz další pravidlo) přes aplikaci logických, statistických, matematických, analytických, modelovacích, experimentálních a dalších metod až po ověřování dosažených výsledků, jejich nezaujatou interpretaci a formulaci vědeckých závěrů. Mají-li být takto vyslovené závěry pravdivé, nesmí autor zapomenout uvést všechny faktory a okolnosti, které vedou k omezení jejich vlastní vypovídací schopnosti.

\section{Pravidlo druhé: Slyš pravdu!}

Aby vědec mohl sám rozpoznávat, co je a co není pravda, musí umět hlavně naslouchat. Nelze nalézt pravdu, aniž bychom předtím neprovedli podrobnou a přesně zaměřenou rešerši odborné literatury. Kdo sám nečte díla ostatních autorů, lehce dojde k názoru, že jeho pravda je absolutní, což je z filozofického hlediska již sám o sobě nesmysl. Slyšet pravdu však rovněž znamená umět naslouchat

1 Hus, J.: Výklad viery. [Původně sepsáno 1412.]. In: Erben, K. J. (ed.): Mistra Jana Husi Sebrané spisy české z nejstarších známých pramenů. Díl I. Praha, Bedřich Tempský, 1865, s. 7.

2 Na tomto místě bych chtěl poděkovat svému synovci, Jakubovi Markovi, nebot' naše společné diskuse ohledně Husova díla, mi pomohly k utřídění myšlenek a sepsání této předmluvy. 
kritikům a dalším oponentům. Vědec nemůže zavírat oči nad vlastními chybami a musí umět korigovat své myšlení v návaznosti na oprávněnou kritiku.

\section{Pravidlo tř̀tí: Uč sě pravdě!}

Vědeckou práci lze označit za nikdy nekončící proces. Vědec by neměl ustrnout na tom, že dříve dosažené poznání je nepopiratelné. Jinými slovy řečeno, vždycky je třeba mít na paměti, že všechno může být jinak. Jestliže se chceme učit pravdě, nesmíme ovšem přijímat jakékoliv „bláboly“ jen proto, že vyhovují našim závěrům, neboli je třeba umět rozeznávat kvalitní a nekvalitní zdroje.

\section{Pravidlo čtvrté: Miluj pravdu!}

Abychom mohli milovat pravdu, musíme ji především umět vnitřně přijmout. Ostatně, toto pravidlo se týká samotného smyslu vědecké práce. Proč studujeme a bádáme? Je to hlavně proto, abychom získali uznání autorit a náležité peněžní ohodnocení. Pak milujeme spíše pochvalu nadřízených a své bohatství, a vlastně ani nemáme nějaké zvláštní zábrany proti úpravě svých závěrů, pokud povedou ke splnění našich cílů, i kdyby neměly být tyto závěry pravdivé. Jestliže ovšem doopravdy milujeme pravdu, pak se ji ve svém výzkumu snažíme dobrat a aktivně ji šiřit, i kdyby to mělo vést ke snížení našeho vlastního prospěchu.

Současně je třeba si uvědomit, že neexistuje pravda objektivní. Pokud někdo tvrdí, že zastává objektivní pravdu, tak již tím sám o sobě je neobjektivní, nebot' toto jeho tvrzení pouze představuje jeho subjektivní pohled na určitý poznatek. Objektivní vědecká pravda nicméně existuje, nelze ji ovšem jen tak snadno nalézt, takříkajíc o ni zakopnout, ve své podstatě je to iterační nikdy nekončící proces.

\section{Pravidlo páté: Prav pravdu!}

Vědec by si neměl své vlastní poznatky ponechávat pro sebe. Jestliže si myslí, že má pravdu a miluje ji, pak s ní musí seznámit i všechny ostatní, jež téma, kterým se ve své práci zabývá, zajímá. Jinými slovy musí publikovat, přednášet a diskutovat. Dokonce musí vyvinout takové úsilí, aby jeho závěry byly uveřejněny v takových časopisech či knihách, odprezentovány na takových konferencích, aby se s jeho dílem mohlo seznámit co nejvíce odborníků.

\section{Pravidlo šesté: Drž pravdu!}

Domnívá-li se vědec, že jeho závěry jsou správné, pak by neměl od nich ustupovat, avšak pokud naopak dojde k poznání, že jeho dříve uveřejněné závěry byly mylné, pak by měl být také naopak schopen od nich ustoupit. Nesmíme zapomínat, že každé vědecké poznání je poplatné stavu poznání ve své době. Není tedy ostudou, jestliže autor dokáže přehodnotit své závěry na základě nových poznatků, ale nesmyslem je na nich naopak trvat jen proto, aby snad nedošlo k poškození jeho jména. 
P̌̌EDMLUVA - Marek, P.: Sedm Husových pravidel o pravdě.

\section{Pravidlo sedmé: Bran̆ pravdu až do smrti!}

Neposledním úkolem vědce by měla být obhajoba pravdy, a to nejen jeho vlastních poznatků, ale i poznatků jeho vědeckých spolupracovníků či dokonce kritiků. Požadavek bránit pravdu až do smrti vzal Mistr Jan Hus velmi vážně a dokázal za ní stát jak před koncilem kostnickým tak i přímo na hranici tvárí v tvář očekávané smrti. Pro nás vědce 21 . století snad bude stačit, když vytrváme na své pravdě až do svého vědeckého stárí, a podobný osud jako Mistra Jan Husa nás čekat nebude.

prof. Ing. Petr Marek, CSc.

předseda redakční rady

Českého finančního a účetního časopisu 